Article

\title{
Local Factors Controlling Gully Development in a Mediterranean Environment
}

\author{
Bruno Martins ${ }^{1, *(\mathbb{D}}$, Adélia Nunes ${ }^{2} \mathbb{D}$, Ana Meira-Castro ${ }^{3} \mathbb{D}$, Luciano Lourenço ${ }^{2} \mathbb{D}$ and Carlos Hermenegildo ${ }^{4}$ \\ 1 CEGOT (Centre of Studies on Geography and Spatial Planning), RISCOS, University of Coimbra, \\ 3004-530 Coimbra, Portugal \\ 2 FLUC-Department of Geography and Tourism, RISCOS and CEGOT-Centre of Studies in Geography and \\ Spatial Planning, 3004-530 Coimbra, Portugal; adelia.nunes@fl.uc.pt (A.N.); luciano@uc.pt (L.L.) \\ 3 School of Engineering, Polytechnic of Porto (ISEP), Rua Dr. António Bernardino de Almeida, 431, \\ 4200-072 Porto, Portugal; amc@isep.ipp.pt \\ 4 Faculty of Natural Sciences, Engineering and Technology, Universidade Lusófona do Porto, \\ 4000-098 Porto, Portugal; p5270@ulp.pt \\ * Correspondence: bruno.martins@uc.pt
}

Citation: Martins, B.; Nunes, A.; Meira-Castro, A.; Lourenço, L.; Hermenegildo, C. Local Factors Controlling Gully Development in a Mediterranean Environment. Land 2022, 11, 204. https://doi.org/ 10.3390/land11020204

Academic Editors: Gergely Tóth, Eva Ivits and Bozena Smreczak

Received: 30 November 2021

Accepted: 25 January 2022

Published: 28 January 2022

Publisher's Note: MDPI stays neutral with regard to jurisdictional claims in published maps and institutional affiliations.

Copyright: (c) 2022 by the authors. Licensee MDPI, Basel, Switzerland. This article is an open access article distributed under the terms and conditions of the Creative Commons Attribution (CC BY) license (https:// creativecommons.org/licenses/by/ $4.0 /)$.

\begin{abstract}
Gullies contribute very efficiently to soil loss and degradation, particularly in Mediterranean environments. While natural factors are involved in gully formation and further development, anthropic action is almost always an element. Knowledge of formation and development factors are important if soil protection strategies and measures are to be effective. In this paper, we identify the most important factors in the development of gullies in a Mediterranean setting based on a study of the Alva gully (central Portugal). Its development in the last four years is examined, based on a study of the modification of its morphological characteristics. The analysis was based on principal component analysis (PCA) to estimate the correlation between the quantitative characteristics, geomorphological processes, and biophysical variables. The results show that the main factors that seem to control the spatial variation of soil erosion are the soil penetration resistance, slope, slope shape, and vegetation cover.
\end{abstract}

Keywords: gully development; sediment production; Mediterranean environment

\section{Introduction}

Water erosion problems are a major factor in causing environmental impacts, including land degradation [1]. This has adverse effects on water quality, ecology, and terrestrial and aquatic habitats. However, in many regions, soil degradation has severe impacts on the economy of the country, the family, and on the individual. The water erosion processes associated with gully formation often lead to considerable agricultural damage as the soil loses productive capacity and water loses quality. The displaced material can end up being deposited in areas of high economic interest where it might destroy more profitable production. In certain circumstances, it can reach watercourses which, in flood peaks, will carry a larger solid load than before [1-5]. The outcome could be to generate massive economic damage to humankind [2-11]. Several authors [12,13] state that in some areas more than $80 \%$ of sediment is produced by gully erosion, making it one of the most destructive types [14,15].

A gully is an erosion channel caused by irregular concentrated water flow, often throughout and immediately after a heavy rainfall event (Soil Science Society of America, 2008). Authors such as Foster (1986) [16] and Poesen et al. (2003) [17] consider a classic gully to be a channel deep enough, generally $>0.5 \mathrm{~m}$, to interfere with normal ploughing operations. Gullies are often found in mountainous regions [18-29]. But they are even more common in the semi-humid and semi-arid regions of Mediterranean countries [30-38].

The impact of gullies as a factor in soil degradation is very important in these regions. Many causes of gully erosion have been identified and these include natural and 
human-induced soil erosion processes [13,17]. A number of anthropogenic factors not only help to establish gullies, but very often they contribute to their rapid development and erosive capacity [39-45]. Most notable are forest fires, deforestation, and other causes of erosion, especially inappropriate cultivation and irrigation systems, overgrazing, log haulage tracks, road building, and urbanization. Furthermore, various natural factors are seen as fundamental to the formation of gullies, including topographic thresholds (such as slope gradients and soil crusts), soil and lithologic controls (soil, lithologic and geomorphology factors; soil crusting; piping), land use and climate change (present and past changes in land use) [13,17]. All these drivers together confirm the importance of increasing the urgency for gully erosion research and reinforcing the combined efforts of monitoring, modeling, and managing soil loss processes and landscape degradation [11]. In general, the progress of gullies is monitored by one of two methods. The first approach is based on the measurement of the material at the exit of a gully system [46]. However, this method does not allow the analysis of the gully channel's development. The second method is based on the use of topographic data sets, DEM, digital surface models (DSM) or point cloud (PC) [46-48] and aims to define the evolution of the morphological characteristics of a gully over a period of time.

In most cases, however, the constraint in spatial definition makes topographic variations undetectable for most gullies [47], which implies the use of both very high resolution DEMs [46], and topographic data obtained from photographs using photogrammetric techniques [49]. More recently, a new source of data provided by the LIDAR survey has been used to detect gullies in forested areas [47] that allows measurements of small variations of a few centimeters. However, this approach also has some limitations related to continuous data collection from deeply incised gullies [47]. The number of papers recognizing the problems related to gullies in Portugal, and the repeated impacts on soil and environment, has increased significantly in the past few years, especially related to the quantification of soil erosion rates and, primarily, gully evolution. Nevertheless, works on the monitoring of a permanent gully system are still scarce [38,49], which could perhaps be related to the very time-consuming and labor-intensive nature of the task. Such works are in fact particularly interesting in that they help to identify the main elements in the origin and evolution of gullies. They could thus contribute to developing strategies that are more effective for soil conservation work. The main objectives of this work were (a) to analyze the evolution of a gully located on a granite substratum in a Mediterranean environment, over a 5-year study period between 2015 and 2019, and (b) to identify the main factors responsible for the spatial and temporal differences in erosion rates observed within the specified gully.

\section{Materials and Methods}

\subsection{Study Area}

The gully under study is located on the right bank of the River Alva, downstream of the village of Penalva de Alva and opposite Caldas de São Paulo, in the municipality of Oliveira do Hospital (Figure 1). It develops between road bends on a steep incline of between 20 and $30 \%$. This is a forest area that was affected by several forest fires between August 2013 and 2018.

The study area, i.e., where the ravine is located, is part of the Maciço Antigo [Ancient Massif] which lies within the Central Iberian Zone [50]. From the lithological point of view, it is part of the Beira uraniferous province and is essentially composed of granitic rocks, with a predominance of coarse-grained porphyroid granite, calco-alkaline in nature, and sometimes with orientation of megacrystals [51]. 


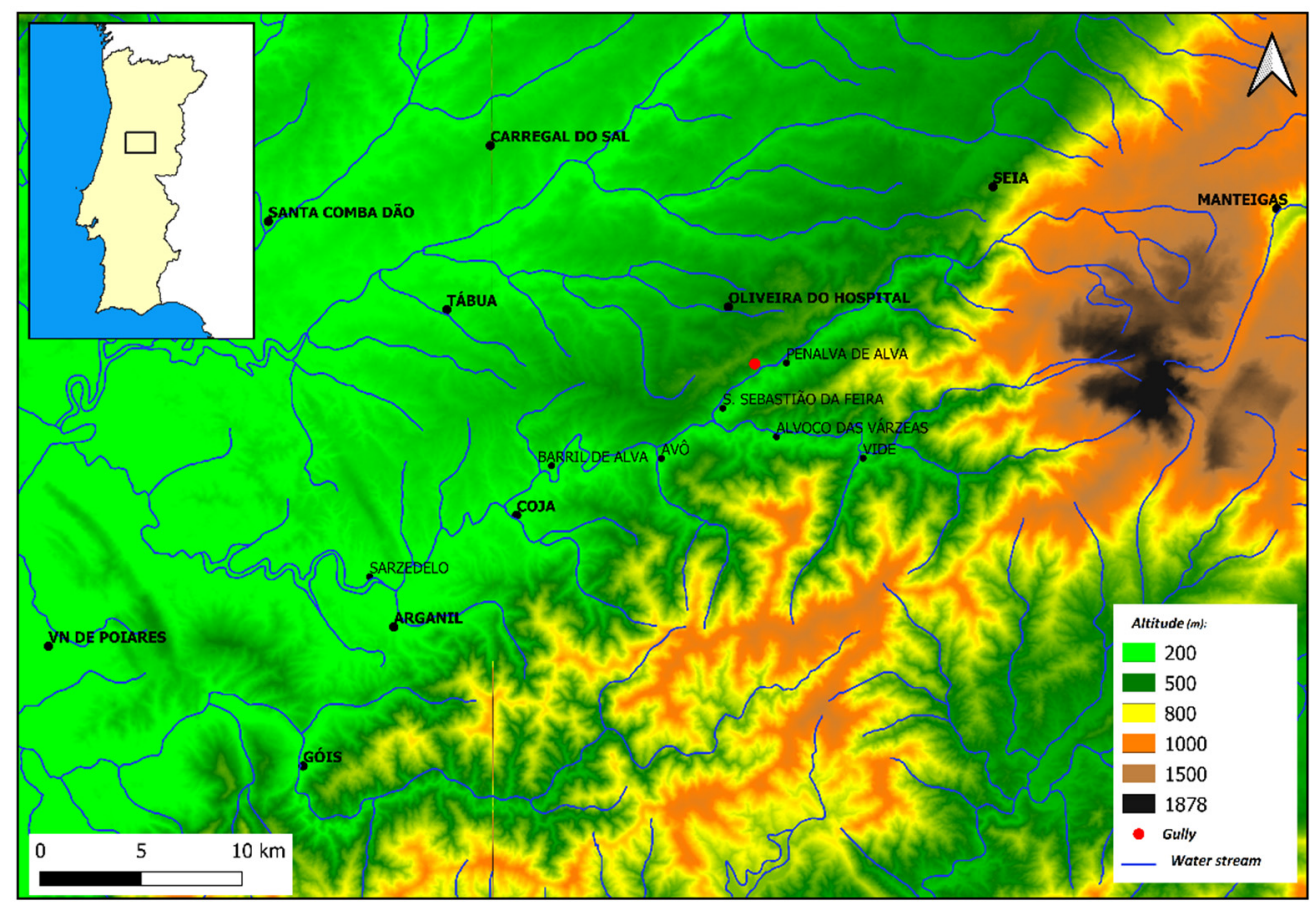

Figure 1. Location of the study area and gully.

The gully is bedded on regolith created by the weathering of granite. From the granulometric point of view, coarse sands predominate over fine sands. The values of the silty-clayey fraction are very small. The modal class corresponds to sands with a diameter of $2 \mathrm{~mm}$, and the central tendency measures (median, mean, and graphic mean) point to values between $1.5 \mathrm{~mm}, 1.3 \mathrm{~mm}$, and $1.5 \mathrm{~mm}$, respectively. The calibration values confirm the predominance and concentration of sediment in the coarse fractions, revealing the removal of the concentration around the mean. The asymmetry values also suggest an enrichment in coarse relative to fine sediment. The kurtosis value indicates a leptokurtic curve.

As in most of the country, the climate of the study area has Mediterranean characteristics (Cs). The analysis of the temperature-rainfall graphs from the meteorological stations in the official IPMA network [Portuguese Institute of the Sea and Atmosphere] indicates only two dry months (July and August) (rainfall in mm equal to or less than twice the average monthly temperature in ${ }^{\circ} \mathrm{C}$ ). The annual rainfall ranges from $1100 \mathrm{~mm}$ on the lowest altitude slope to $1300 \mathrm{~mm}$ at higher altitudes. Rainfall can sometimes be very heavy and concentrated.

\subsection{Monitoring Morphological Changes in the Gully and Statistical Analysis}

The gully and slope were split into cross-sectional profiles, separated by $2 \mathrm{~m}$. Depth and width were obtained from a BOSCH GR 240 Professional measuring ruler and a BOSCH GLM 40 laser meter. Depth was determined from the perpendicular distance between the base of the gully and a horizontal bar. Field surveys were conducted in June 2015 and February 2019. Accumulation and erosion areas, as well as volume, were determined during the field surveys using SURFER 8.0 (Scientific Software Corp., Sandy, UT, USA) and ArcGIS 10.2 (Esri, Portugal). The biophysical variables were determined for each section, as follows:

(a) The slope (\%) (determined from the use of a graduated iron bar, in order to obtain the difference in level measurements for a distance of $1 \mathrm{~m}$ ); (b) the slope profile (concave/convex/linear); (c) the average vegetation cover percentage (\%) (obtained using a $1 \mathrm{~m}^{2}$ gridded square, photographed on the ground, digitalized and the percentage value of each plot calculated); (d) the average soil resistance to penetration, in $\mathrm{kg} \mathrm{cm}^{-2}$ (obtained using a pocket penetrometer, Eijkelkamp®_-Giesbeek, The Netherlands); (e) the soil resistance to torsion, in $\mathrm{kg} \mathrm{cm}^{-2}$ (obtained using an Eijkelkamp® pocket torsor). Total 
of 402 samples were taken for analysis of the soil penetration resistance and torsional strength obtained at several points of gully wall, or at least, in the topsoil, at the midpoint and at the base of the gully wall and averaged [33,52-56].

The data analysis was carried out using MATLAB (R2020). In order to identify the primary factors influencing denudation/deposition processes at local scale, principal component analysis (PCA) was considered. Before PCA was carried out, the suitability of implementing this multivariate technique was first assessed. A correlation matrix was created to assess possible collinearity among the variables. A correlation coefficient threshold between variables of $|\mathrm{r}|>0.7(p<0.05)$ was considered an appropriate indicator for the point where collinearity begins to severely distort model estimation and subsequent prediction [57].

\section{Results}

The total length of the studied gully is $116 \mathrm{~m}$, and it influences an area close to $0.03 \mathrm{ha}$. On average, the gully is about $1.5 \mathrm{~m}$ wide and nearly $2 \mathrm{~m}$ deep (Table 1 ).

Table 1. Most important morphological characteristics of gully, sourced in 2019.

\begin{tabular}{|c|c|c|c|c|c|c|c|c|c|c|}
\hline \multicolumn{11}{|c|}{ Coordinates } \\
\hline $\mathrm{x}$ & Y & $\begin{array}{c}\text { Total } \\
\text { length }(\mathrm{m})\end{array}$ & $\begin{array}{c}\text { Mean } \\
\text { width }(\mathrm{m})\end{array}$ & $\begin{array}{l}\text { Maximum } \\
\text { width value } \\
(\mathrm{m})\end{array}$ & $\begin{array}{c}\text { Mean } \\
\text { depth (m) }\end{array}$ & $\begin{array}{l}\text { Maximum } \\
\text { depth value } \\
(\mathrm{m})\end{array}$ & WDR * & $\underset{* *}{\text { SSAGH }}$ & $\begin{array}{l}\text { Channel slope } \\
\qquad\left(\mathrm{m} \mathrm{m}^{-1}\right)\end{array}$ & $\begin{array}{c}\text { Plan area } \\
\left(\mathrm{m}^{2}\right)\end{array}$ \\
\hline 40.3337 & -7.8471 & 116 & 1.33 & 9.30 & 2.02 & 6.65 & 2.1 & 0.39 & 0.36 & 333.5 \\
\hline
\end{tabular}

A more detailed analysis shows that the gully was formed from the upstream road, first over hard rock, where the incision is incipient and only a few centimeters in depth at its deepest. Then, when it started to develop over altered rock, it quickly gained depth, while its width increased, although with local bottlenecks. The material through which the downstream ravine develops is characterized by the predominance of sandy material, with less of the silty-clayey fraction. The modal class corresponds to sands of $2 \mathrm{~mm}$ diameter, and the measures of central tendency (median, mean and graphical mean) point to values between $1.5 \mathrm{~mm}, 1.3 \mathrm{~mm}$, and $1.5 \mathrm{~mm}$ respectively. The calibration values confirm the predominance and concentration of the sandy material (the sum of the sediments of more than $1 \mathrm{~mm}$ amounts to more than half of the sediment) revealing a shift of the concentration around the mean. The asymmetry values also suggest an enrichment in coarse versus fine, suggesting a leptokurtic particle size distribution. Given the morphological characteristics of the ravine, two sections are identified, these being gully Section 1 (GS1), which is developed upstream of a bedrock, while gully Section 2 (GS2) develops between the bedrock and the cross-section where the gully enlargement becomes obvious. The main features are described by the variables listed in Table 1. From a morphological point of view, GS1 is essentially a shallow gully sector, with an average width of less than $1 \mathrm{~m}$ and a depth close to $0.23 \mathrm{~m}$. Considering the relationship between width and depth, the mean WDR value obtained is close to 3.5. The correlation between gully depth and width is positive and moderate $(r=0.80)$ and the correlation between WDR and channel slope is 0.09 . Sector GS2 is about $78 \mathrm{~m}$ long. In terms of width, the average value is more than $1 \mathrm{~m}$, but it is higher than $5 \mathrm{~m}$ in many segments of the gully. The average depth is approximately $3 \mathrm{~m}$. The mean WDR value obtained is 1.37 . The correlation between gully depth and width is positive and strong $(r=0.93)$. The correlation between WDR and channel slope is negative $(\mathrm{r}=-0.34)$.

\subsection{Gully Evolution}

The main bed development of the gully is presented in Figure 2 and is based on the two levelling surveys carried out in June 2015 and February 2019. As we can see, the most expressive modifications have occurred in GS2. Although there are areas of deposition and 
denudation, deposition from the gully banks and the upstream sectors perishes. Deposition occurs mainly between 100 and $104 \mathrm{~m}$ and between 118 and $124 \mathrm{~m}$. Denudation occurs between 84 and $94 \mathrm{~m}$ (Figure 2).
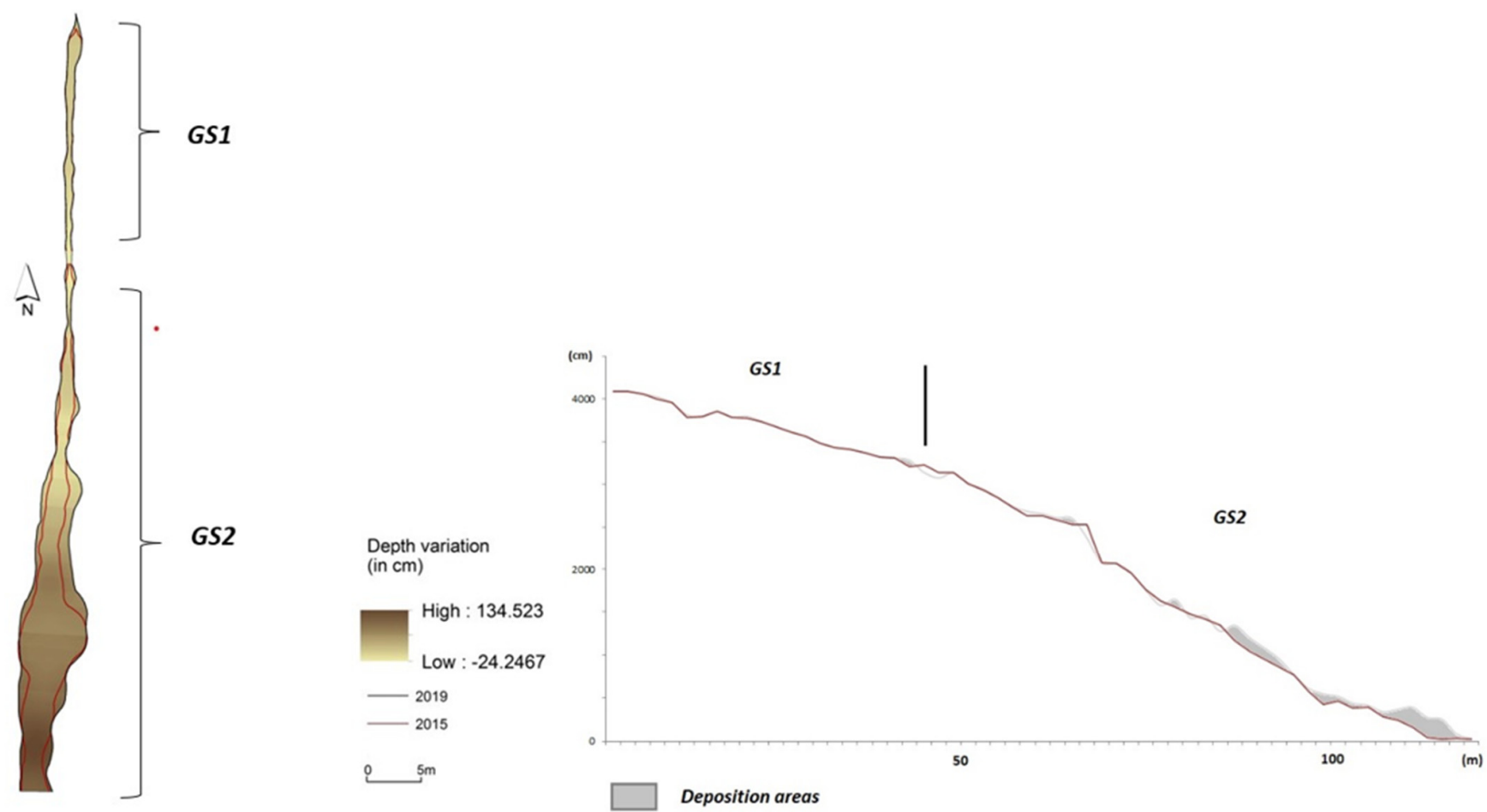

Figure 2. DEM differences between 2015 and 2019 levelling survey. Light where the channel has deepened, dark where there has been accumulation.

\subsection{Key Factors of Enlargement and Depth Variation}

Table 2 summarizes the exploratory variables best correlated with gully enlargement variation and the independent variables. Slope shape and penetrometer resistance showed the highest correlation values. The correlation of slope shape is positive (r: 0.582 ; $p$-value $<0.01)$ while the penetrometer resistance is negative ( $\mathrm{r}:-0.529 ; p$-value $<0.01)$. The results also show correlation coefficients that are statistically significant with the depth variation (r: 0.389; $p$-value < 0.01) and vegetation cover $(\mathrm{r}: 0.300 ; p$-value < 0.05) variables.

Considering only GS2, where the most significant results were obtained in the variation in depth, WDR, penetrometer resistance, slope shape, slope, and width variation were the ones with the best correlations (Table 3). The WDR and the resistance to penetration has a significant negative correlation with depth variation, $\mathrm{r}:-0.707(p$-value $<0.01)$ and r: -566 ( $p$-value $<0.01)$ respectively. The slope also has a negative correlation but not so significant $(\mathrm{r}:-0.391 ; p$-value $<0.05)$. There is a positive correlation with slope shape (r: 0.367; $p$-value < 0.05) and enlargement variation (r: 0.324; $p$-value $<0.05$ ). 
Table 2. Spearman correlation between depth variation and some independent variables.

\begin{tabular}{|c|c|c|c|c|c|c|c|c|c|}
\hline & & Depth Variation & Width Variation & WDR & Slope Shape & Vegetation Cover & Slope & Resist. to Penet. & Resist. to Torc. \\
\hline \multirow{2}{*}{ Width variation } & Correlation Coefficient & $0.389^{* *}$ & 1 & 0.229 & $0.582^{* *}$ & $0.300 *$ & 0.214 & $-0.529 * *$ & -0.126 \\
\hline & Sig. (2-tailed) & 0.003 & - & 0.084 & 0 & 0.022 & 0.107 & 0 & 0.344 \\
\hline \multirow{3}{*}{ Depth variation } & Correlation Coefficient & 1 & $0.389 * *$ & $-0.586^{* *}$ & $0.391^{* *}$ & -0.123 & -0.182 & $-0.532 * *$ & -0.152 \\
\hline & Sig. (2-tailed) & & 0.003 & 0 & 0.002 & 0.36 & 0.173 & 0 & 0.254 \\
\hline & $\mathrm{N}$ & 38 & 38 & 38 & 38 & 38 & 38 & 38 & 38 \\
\hline
\end{tabular}

${ }^{*}$ Correlation is significant at the 0.05 level (2-tailed); ${ }^{* *}$ correlation is significant at the 0.01 level (2-tailed).

Table 3. Correlation between the variables considered and widening of gully section GS2.

\begin{tabular}{|c|c|c|c|c|c|c|c|c|c|}
\hline & & Width Variation & Depth Variation & WDR & Slope Shape & Vegetation Cover & Slope & Resist. to Penet. & Resist. to Torc. \\
\hline \multirow{3}{*}{$\begin{array}{l}\text { Width variation } \\
\text { of GS2 }\end{array}$} & Correlation Coefficient & 1 & 0.324 * & $-0.707^{* *}$ & $0.367 *$ & -0.249 & $-0.391 *$ & $-0.566^{* *}$ & -0.166 \\
\hline & Sig. (2-tailed) & & 0.047 & 0.000 & 0.024 & 0.132 & 0.015 & 0.000 & 0.319 \\
\hline & $\mathrm{N}$ & 38 & 38 & 38 & 38 & 38 & 38 & 38 & 38 \\
\hline
\end{tabular}

${ }^{*}$ Correlation is significant at the 0.05 level (2-tailed); ${ }^{* *}$ correlation is significant at the 0.01 level (2-tailed). 
The results of applying PCA suggest that the gully widening and deepening are related both to the physical properties of the soil, notably the strength and torsion, and to the shape of the slope. They confirm that the sectors where the gully widens and deepens more are where the soil shows most change, together with increased slope concavity. On the other hand, it also suggests that the sectors where the percentage of vegetation is lower is where there was even more widening and deepening of the channel (Figure 3A).

A

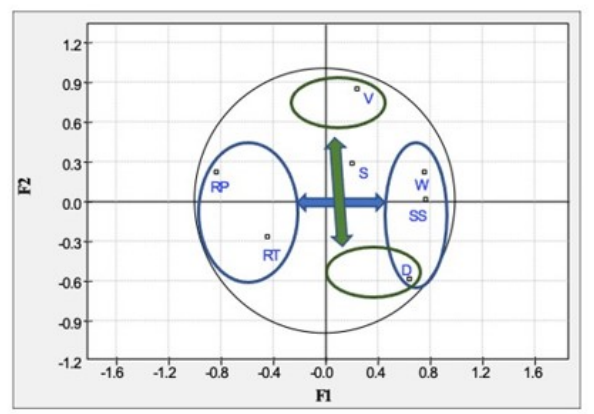

B

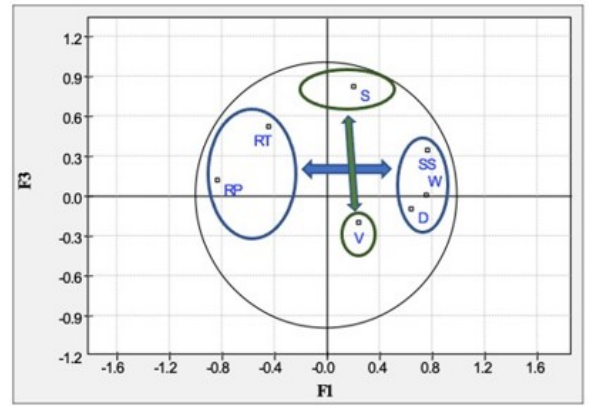

Related $\quad \% \quad$ Related

variables EXP variables

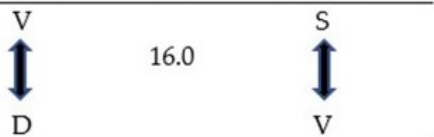

1 represents the opposition on the factorial plan. Also represents the strong negative correlation between the variables in opposition.

Variables names: $\mathrm{D}=$ depth, $\mathrm{W}=$ width, $\mathrm{S}=$ slope, $\mathrm{SS}=$ slope shape, $\mathrm{V}=$ vegetation cover, $\mathrm{RP}=$ resistance

to penetration, $\mathrm{RT}=$ resistance to torsion

Figure 3. ACP output: main correlation between variables according to each factorial axis: (A) factorial axis F1 (explaining 36.9\% of the variables' variability) and factorial axis F2 (explaining 18.6\% of the variables' variability) and (B) factorial axis F1 and factorial axis F3 (explaining 16.0\% of the variables' variability).

The analysis also suggests that the higher slope sectors are those where the percentage of vegetation cover is lower (Figure 3B). This to some extent reinforces the idea that the steep slope areas are also those where the erosive dynamics is greater, as borne out by the widening of the channel and its greater depth. The results suggest an explanation of about $36.9 \%$ when considering the physical properties of the soil, in particular the resistance and the torsion; this figure increases to $55.5 \%$ when the slope gradient is considered, and to $71.6 \%$ when the slope shape is also taken into account.

The results suggest very significant modifications in the gully channel, particularly with respect to widening, especially in the final section. Although the gully is about $116 \mathrm{~m}$ long and the period of analysis relatively short, the steepness of the slope and the friable features of the substrate seem to contribute to this variation. The widening is largely justified by the collapse of material in the gully walls, especially where there is lower resistance to penetration and torsion, and the slope is steeper. Furthermore, forest fires, recurrent over the years, will have aggravated this process.

\section{Discussions}

Gully erosion is without doubt one of the main environmental problems since it contributes effectively to soil loss and degradation. The recovery of areas affected by gullies is generally costly and difficult. Some studies consider the presence of gullies in about $1-5 \%$ of total landscape observation [11], a figure that rises to $10 \%$ in Europe [57-60], 
especially in the Mediterranean area. Given the large number of research works on this topic, one could therefore conclude that knowledge about gully erosion processes, as well as their control, would leave little room for new insights on the topic. This conclusion can be refuted to some extent by some research gaps. More research is certainly needed to understand both the natural and man-made processes of soil erosion, especially their interaction at different spatial and temporal scales. Furthermore, it is critical for us to be able to better predict spatial and temporal scales, to forecast their erosion rates as well as their on-site and off-site impacts, so as to better target erosion control measures. In this study, we have focused on analyzing the evolution of the topographic attributes of the gully and identification of factors which had an influence on the occurrence of erosion (denudation vs. accumulation) between 2015 and 2019. Indeed, the results suggest a very complex spatial distribution of soil erodibility. The results also indicate effective gully dynamics which, although not specifically considered in this work, are certainly expressed as high erosion rates. This conclusion is especially indicated for the gully sector GS2, where a conspicuous enlargement occurred. In recent decades, several gully-erosion models have been developed, usually with the purpose of gully-erosion susceptibility mapping. Most of the time the models resort to the analytic hierarchy process to identify the main factors controlling the process. Examples are probabilistic models, information value, frequency ratio, index of entropy, evidential belief function, weights-of-evidence, certainty factor, and logistic regression. At the same time, remote sensing has enabled the development of high-resolution digital surface models (DSMs) or by photogrammetry that enable detailed morphological analyses of centimeter-order [61-65]. These models are often used for monitoring gullies and measuring erosion rates.

Moreover, the widths, cross-sectional areas, extent, and channel volume of gullies can be obtained from aerial or satellite images. However, gully floor-widths are typically hard to measure from such imagery, often resulting in unreliable results. Furthermore, gully cross-sectional areas are difficult to quantify based on aerial photographs or high-resolution satellite imagery, but are a fundamental prerequisite for estimating discharge volumes. Therefore, they are often obtained through field measurements (e.g., Nachtergaele et al., 2001a, 2001b) [66,67].

Nevertheless, field measurements are also particularly effective, especially in situations where it is hard to identify differences in soil mechanical characteristics using remote sensing. In the study area, the physical characteristics of the soil were identified as part of the fieldwork, making it possible to identify key differences in the evolution of the gully channel in detail. Other factors considered significant in explaining the gully dynamics, such as the shape of the slope and the percentage of vegetation cover, were also acquired from the fieldwork. The shape of the slope is a significant contributing factor to the explanatory model in the evolution of the gully by contributing to the concentration of drainage. The use of DSMs means the shape of the slope can be inferred and so it is often used in hydrological modeling. However, in detailed work, such as the study presented here, the fieldwork allowed the identification of this variable in a very secure way and with a high degree of detail. At the same time, the analysis of the vegetation cover evolution in the field will provide even more reliable results.

In fact, understanding the factors that contribute most to changes in the erodibility of gully is particularly important when it comes to implementing more effective control and mitigation strategies, and for defining the most susceptible areas. However, as Bennett \& Wells (2019) [60] report, the temporal and spatial variation in the erodibility of gully sediments can be quite large even without the involvement of strong forces, and there is no consensus on how to predict such erodibility variation. In our study, the main factors that seem to control the spatial variation in soil erosion are the soil penetration resistance, slope, slope shape, and vegetation cover. Penetration resistance was the most influential factor for spatial variations that occurred in both depth and width. Several studies consider a soil penetrometer can be a good screening tool for soil physical conditions [56,57]. Kılıç et al. (2021) [68] states that penetration resistance is dependent on a 
number of different properties, e.g., bulk density, water content, water potential. In this context, Nunes et al. (2010) [32] also found that soil resistance to penetration follows a similar pattern to bulk density. Erosive processes are in fact determined to some extent by the physical properties of the soil [55-57,69]. According to Olivares et al. (2011) [70], this is because of surface sealing, crusting, soil compaction, poor drainage, impeded root growth, excessive runoff, and accelerated erosion). In this regard, Nunes et al. (2010; 2011) [32,35] found a negative highly significant correlation between soil resistance to penetration and runoff and sediment yield.

The gully development is also favored in footslopes and valley floors since they represent areas where overland flow is concentrated into preferred pathways of flow [68], especially concave hollows adjacent to drainage lines, as opposed to upland convex hillslope sections [69]. Conversely, vegetation cover as offering more protection against overland flow and water erosion show a negative correlation, which agree with the findings of different authors in varied environments [32,35,71-77].

As the model was utilizing a limited set of input parameters based on variables that are easily accessible, the results show a moderate accuracy, meaning that there are several environmental factors related to gully erosion initiation and development that need to be integrated. Although gully contributing factors that are significant in a specific area are not necessarily important in other areas [78-83], local analyses of gullies have nonetheless shown that several environmental factors are related to gully erosion initiation and development. Some are local factors (e.g., soil type), and some depend on the surrounding environment (e.g., land use, climate variability) [33]. The results suggest the importance of local conditions as determinants of gully evolution, which somewhat limits the extrapolation of these results to other areas if these conditions are not considered.

In general, topographic attributes such as upstream drainage area, slope, and plan of curvature are key topographic controls in the formation process [16,80-82]. Soil properties also play an important role in allowing soil particles to detach and travel with overland flow. Soil moisture content can affect the soil critical stress and thus influence the formation and progression of gully erosion [84]. Surrounding land cover and management practices greatly influence vegetation cover and the ability of terrains to slow the overland flow [17].

\section{Conclusions, Limitations, and Further Research}

Monitoring a permanent gully (Centre of Portugal) over a 5-year period using intensive field topographic surveys has enabled us to understand the morphological evolution of the gully. The gully is similar to most gullies in the Alva catchment; thus, it can be regarded as representative of the main gully processes acting on this catchment. Very contrasted behaviors were observed inside the gully. The main factors affecting the spatial variability of erosion rates on bank slope units were slope gradient and slope profile. The gully was split into two units based on the morphological aspects. Units GS1 and GS2 showed low denudation rates, although they are areas that collect most of the runoff. The absence of regolith did not allow the gully excavation. The main changes occurred in GS3 between 86 $\mathrm{m}$ and $94 \mathrm{~m}$. A convex bank slope unit has denudation rates greater than a concave bank slope, especially with regard to the gully widening.

Despite the contributions provided by this study, certain limitations must be recognized, mainly relating to the methodology and research process. The first lies in the fact that, as gullying is a threshold-dependent process controlled by a wide range of factors [13] such as topography, geology, soil type, land use/cover in the drainage areas, and the gully was not gauged, it is difficult to infer how it responds to input (rainfall) and to the combined effects of the mentioned factors. Moreover, although it is assumed that the gully material exposed to erosion is composed primarily of cohesive and non-cohesive clastic sediment, another gap in this research is due to an insufficient understanding of the controlling parameters that could affect denudation vs. accumulation. They can also include physical, geochemical, and biological properties as well as land management practices, all of which can vary in time. In this regard, the numerous fires that have occurred in the study area in 
recent years, which will certainly have influenced the physical, chemical, and biological properties of the soil, as well as the percentage of plant cover, are therefore essential to understanding the hydrological and erosional response in different sections, and they have not been taken into consideration.

Author Contributions: Conceptualization, B.M., A.N., A.M.-C. and L.L.; methodology, B.M., A.N., A.M.-C. and L.L.; software, B.M., A.N., A.M.-C., L.L. and C.H.; validation, B.M., A.N., A.M.-C. and L.L.; formal analysis, B.M., A.N. and A.M.-C.; investigation, B.M., A.N., A.M.-C. and L.L.; writing-original draft preparation, B.M. and A.N. All authors have read and agreed to the published version of the manuscript.

Funding: This research received support from the Centre of Studies in Geography and Spatial Planning (CEGOT), funded by national funds through the Foundation for Science and Technology (FCT) under the reference UIDB/04084/2020.

Conflicts of Interest: The authors declare no conflict of interest.

\section{References}

1. Bufalo, M.; Nahon, D. Erosional processes of Mediterranean badlands: A new erosivity index for predicting sediment yield from gully erosion. Geoderma 1992, 52, 133-147. [CrossRef]

2. Krause, A.; Franks, S.; Kalma, J.; Loughran, R.; Rowan, J. Multi parameter fingerprinting of sediment deposition in a small gullied catchment in SE Australia. Catena 2003, 53, 327-348. [CrossRef]

3. Martinez-Casasnovas, J.A. A spatial information technology approach for the mapping and quantification of gully erosion. Catena 2003, 50, 293-308. [CrossRef]

4. Vente, J.; Poesen, J.; Arabkhedri, M.; Gert Verstraeten, G. The sediment delivery problem revisited. Prog. Phys. Geogr. 2007, 31, 155-178. [CrossRef]

5. Bergonse, R.; Reis, E. Controlling factors of the size and location of large gully systems: A regression-based exploration using reconstructed pre-erosion topography. Catena 2011, 147, 621-631. [CrossRef]

6. Ben Slimane, A.; Raclot, D.; Evrard, O.; Sanaa, M.; Lefevre, I.; Le Bissonnais, Y. Relative contribution of rill/interrill and gully/channel erosion to small reservoir siltation in Mediterranean environments. Land Degrad. Dev. 2015, 27, 785-797. [CrossRef]

7. Ayele, G. A biophysical and economic assessment of a community-based rehabilitated gully in the Ethiopian highlands. Land Degrad. Dev. 2016, 27, 270-280. [CrossRef]

8. Golosov, V.; Yermolaev, O.; Rysin, I.; Vanmaercke, M.; Zaytseva, M. Mapping and spatial-temporal assessment of gully density in the Middle Volga region, Russia. Earth Surf. Processes Landf. 2018, 43, 2818-2834. [CrossRef]

9. Marzolff, I.; Pani, P. Dynamics and patterns of land levelling for agricultural reclamation of erosional badlands in Chambal Valley (Madhya Pradesh, India). Earth Surf. Processes Landf. 2018, 43, 524-542. [CrossRef]

10. Sidle, R.C.; Jarihani, B.; Kaka, S.I.; Koci, J.; Al-Shaibani, A. Hydrogeomorphic processes affecting dryland gully erosion: Implications for modelling. Prog. Phys. Geogr. Earth Environ. 2019, 43, 030913331881940. [CrossRef]

11. Poesen, J. Soil erosion in the Anthropocene: Research needs. Earth Surf. Processes Landf. 2018, 43, 64-84. [CrossRef]

12. Cerdà, A. Parent Material and Vegetation Affect Soil Erosion in Eastern Spain. Soil Sci. Soc. Am. J. 2019, 63, 362-368. [CrossRef]

13. Valentin, C.; Poesen, J.; Li, Y. Gully erosion: Impacts, factors and control. Catena 2005, 63, 132-153. [CrossRef]

14. Mekonnen, M.; Keesstra, S.D.; Baartman, J.E.; Ritsema, C.J.; Melesse, A.M. Evaluating sediment storage dams: Structural off-site sediment trapping measures in northwest Ethiopia. Cuad. Investig. Geogr. 2015, 41, 16. [CrossRef]

15. Assefa, E.; Hans-Rudolf, B. Farmers' perception of land degradation and traditional knowledge in Southern Ethiopia-Resilience and stability. Land Degrad. Dev. 2016, 27, 1552-1561. [CrossRef]

16. Foster, G.R. Understanding Ephemeral Gully Erosion. In Soil Conservation, Assessing the National Research Inventory; National Research Council, Board on Agriculture 2, National Academy Press: Washington, DC, USA, 1986; pp. 90-118.

17. Poesen, J.; Nachtergaele, J.; Verstraeten, G.; Valentin, C. Gully erosion and environment change: Importance and research needs. Catena 2003, 50, 91-133. [CrossRef]

18. Wainwright, J.; Mathys, N.; Esteves, M. Gully erosion in mountain areas: Processes, measurement, modelling and regionalization. Earth Surf. Processes Landf. 2016, 31, 133-134. [CrossRef]

19. Brierley, G.; Stankoviansky, M. Geomorphic responses to land use change. Catena 2003, 51, 173-179. [CrossRef]

20. Naimi, M. Dynamique de l'érosion par Ravinement Dans le Bassin Versant du Rif Occidental au Maroc. Sci. Changements Planétaires/Sécheresse 2003, 14, 95-100.

21. Kefi, M.; Yoshino, K.; Setiawan, Y. Assessment and mapping of soil erosion risk by water in Tunisia using time series MODIS data. Paddy Water Environ. 2012, 10, 59-73. [CrossRef]

22. Daba, S.; Rieger, W.; Strauss, P. Assessment of gully erosion in eastern Ethiopia using photogrammetric techniques. Catena 2003, 50, 273-291. [CrossRef] 
23. Walker, S.J.; van Dijk, A.I.J.M.; Wilkinson, S.N.; Hairsine, P.B. A comparison of hillslope drainage area estimation methods using high-resolution DEMs with implications for topographic studies of gullies. Earth Surf. Processes Landf. 2021, 46, 2229-2247. [CrossRef]

24. Zhu, T.; Xu, X.; Erosion, G. Watershed Erosion Processes; Nature Switzerland AG 2021; Springer: Cham, Switzerland, 2021 ; pp. 41-67. [CrossRef]

25. Tang, J.; Liu, G.; Xie, Y.; Dun, X.; Wang, D.; Zhang, S. Ephemeral gullies caused by snowmelt: A ten-year study in northeastern China. Soil Tillage Res. 2021, 212, 105048. [CrossRef]

26. Frankl, A.; Nyssen, J.; Vanmaercke, M.; Poesen, J. Gully prevention and control: Techniques, failures and effectiveness. Earth Surf. Processes Landf. 2021, 46, 220-238. [CrossRef]

27. Bogale, A.; Aynalem, D.; Adem, A.; Mekuria, W.; Tilahun, S. Spatial and temporal variability of soil loss in gully erosion in upper Blue Nile basin, Ethiopia. Appl. Water Sci. 2021, 10, 106. [CrossRef]

28. Roy, S. Influence of Road-Stream Crossing on the Initiation of Gully: Case Study from the Terai Region of Eastern India. In Gully Erosion Studies from India and Surrounding Regions; Springer Nature: Cham, Switzerland, 2020; pp. 251-263. [CrossRef]

29. Nyssen, J.; Poesen, J.; Moeyersons, J.; Luyten, E.; Veyret-Picot, M.; Deckers, J.; Haile, M.; Govers, G. Impact of road building on gully erosion risk: A case study from the Northern Ethiopian Highlands. Earth Surf. Processes Landf. 2002, 27, 1267-1283. [CrossRef]

30. Selkimäki, M.; González-Olabarria, J.R. Assessing gully erosion occurrence in forest lands in Catalonia (Spain). Land Degrad. Dev. 2017, 28, 616-627. [CrossRef]

31. Luciano, L.; Adélia, N.; António, B.-G.; António, V. Soil Erosion after Wildfires in Portugal: What Happens When Heavy Rainfall Events Occur? Soil Erosion Edited by: Danilo Godone and Silvia Stanchi; InTech-Open Access Company: London, UK, 2012; ISBN 980-953-307-558-2.

32. Nunes, J.P.; Seixas, J.; Keizer, J.J.; Ferreira, A.J.D. Sensitivity of runoff and soil erosion to climate change in two Mediterranean watersheds. Part II: Assessing impacts from changes in storm rainfall, soil moisture and vegetation cover. Hydrol. Process. 2009, 23, 1212-1220. [CrossRef]

33. Meira-Castro, A.; Carvalho, J.; Meixedo, J. A qualitative description of soil parameters variation due to a prescribed fire in Portuguese northwestern forests using Fuzzy Boolean Nets-The case study of Cabreira mountain. Geoderma 2012, 191, 89-96. [CrossRef]

34. Meira-Castro, A.; Shakesby, R.; Espinha Marques, J.; Doerr, S.; Meixedo, J.; Teixeira, J.; Chamine, H. Effects of prescribed fire on surface soil in a Pinus pinaster plantation, northern Portugal. Environ. Earth Sci. 2015, 73, 3011-3018. [CrossRef]

35. Nunes, J.P.; Seixas, J.; Pacheco, N.R. Vulnerability of water resources, vegetation productivity and soil erosion to climate change in Mediterranean watersheds. Hydrol. Process. 2008, 22, 3115-3134. [CrossRef]

36. Martins, B.; Meira-Castro, A.; Nunes, A.; Lourenço, L. The development of gullies in a Mediterranean environment: The example of the Corgo gully (central Portugal). Energy Rep. 2020, 6, 794-799. [CrossRef]

37. Martins, B.; Castro, A.C.M.; Ferreira, C.; Lourenço, L.; Nunes, A. Gullies mitigation and control measures: A case study of the Seirós gullies (North of Portugal). Phys. Chem. Earth 2019, 109, 26-30. [CrossRef]

38. Douglas, I.; Pietroniro, A. Predicting road erosion rates in selectively logged tropical rain forests. In Erosion Prediction in Ungauged Basins, Integrating Methods and Techniques, Proceedings of an International Symposium Sapporo, Japan, 8-9 July 2003; De Boer, D., Froehlich, W., Mizuyama, T., Eds.; IAHS Press: Wallingford, UK, 2003; pp. 199-205.

39. Ezezika, O.C.; Adetona, O. Resolving the gully erosion problem in Southeastern Nigeria: Innovation through public awareness and community-based approaches. J. Soil Sci. Environ. Manag. 2011, 2, 286291. Available online: http:/ /www.academicjournals. org/journal/JSSEM/articleabstract/8BBD5123409 (accessed on 15 October 2020).

40. Kheir, R.; Wilson, J.; Deng, Y. Use of terrain variables for mapping gully erosion susceptibility in Lebanon. Earth Surf. Processes Landf. 2007, 32, 1770-1782. [CrossRef]

41. Nwilo, P.; Olayinka, D.; Uwadiegwu, I.; Adzandeh, A. An assessment and mapping of gully erosion hazards in Abia State: A GIS Approach. J. Sustain. Dev. 2011, 4, 196-211. [CrossRef]

42. Nyssen, J.; Moeyersons, J.; Poesen, J.; Deckers, J.; Mitiku, H. The environmental significance of the remobilisation of ancient mass movements in the Atbara-Tekeze headwaters, Northern Ethiopia. Geomorphology 2002, 49, 303-322. [CrossRef]

43. Deng, Q.; Qin, F.; Zhang, B.; Wang, H.; Luo, M.; Shu, C.; Liu, H.; Liu, G. Characterizing the morphology of gully cross-sections based on PCA: A case of Yuanmou Dry-Hot Valley. Geomorphology 2015, 228, 703-713. [CrossRef]

44. Mathys, N.; Brochot, S.; Meunier, M. L'érosion des Terres Noires dans les Alpes du sud: Contribution à l'estimation des valeurs annuelles moyennes (bassins versants expérimentaux de Draix, Alpes de Haute Provence, France). Rev. Geogr. Alp. 1996, 84, 17-27. [CrossRef]

45. Prodanović, D.; Stanić, M.; Milivojević, V.; Simić, Z.; Arsić, M. DEM-based GIS algorithms for automatic creation of hydrological models data. J. Serb. Soc. Comput. Mech. 2009, 3, 64-85.

46. Báčová, M.; Krása, J.; Devátý, J.; Kavka, P.A. GIS method for volumetric assessments of erosion rills from digital surface models. Eur. J. Remote Sens. 2009, 52 (Suppl. 1), 96-107. [CrossRef]

47. Xu, Y.; Yue, D.; He, P. Point cloud segmentation of gully based on characteristic difference using airborne lidar data. Int. Arch. Photogramm. Remote Sens. Spat. Inf. Sci. 2017, XLII-2/W7, 307-311. [CrossRef] 
48. Khalili, A.; Raclot, D.; Habaeib, H.; Lamachère, J.M. Factores and processes of permanent gully evolution in a Mediterranean marly environment (Cape Bon, Tunisia). Hidrol. Sci. J. 2013, 58, 1519-1531. [CrossRef]

49. Zante, P.; Collinet, J.; Leclerc, G. Cartographie des Risques Érosifs sur le Bassin Versant de la Retenue Collinaire d'Abdessadok (Dorsale Tunisienne); Montpellier, France, 2003. Available online: https://agritrop.cirad.fr/553389/ (accessed on 28 November 2021).

50. Junta de Energia Nuclear (JEN). A Província Uranífera do Centro de Portugal. Suas Características Estruturais, Tectónicas e Metalogénicas; Junta de Energia Nuclear: Lisboa, Portugal, 1968.

51. Dias, R.; Ribeiro, A.; Coke, C.; Rodrigues, J.; Pereira, E.; Rebelo, J.; Moreira, N. Evolução Estrutural dos Sectores Setentrionais do Autóctone da Zona Centro-Ibérica, in Geologia de Portugal; Livraria Escolar Editora: Lisbon, Portugal, 2011.

52. Wang, H.; Zhang, G.-H.; Li, N.-N.; Zhang, B.-J.; Yang, H.-Y. Variation in soil erodibility under five typical land uses in a small watershed on the Loess Plateau, China. Catena 2019, 174, 24-35. [CrossRef]

53. Coelho, C.O.; Ferreira, A.J.; Laouina, A.; Boulet, A.-K.; Chaker, M.; Nafaa, R.; Naciri, R.; Regaya, K.; Hamza, A.; Carvalho, T.M.; et al. Changes in land-use and their impact on erosion rates and overland flow generation in the Maghreb region, Revue des sciences de l'eau. J. Water Sci. 2004, 17, 163-180. [CrossRef]

54. Luk, S.-H.; Hamilton, H. Experimental effects of antecedent moisture and soil strength on rainwash erosion of two luvisols, Ontario. Geoderma 1986, 37, 29-43. [CrossRef]

55. Marzolff, I.; Poesen, J. The potential of 3D gully monitoring with GIS using high-resolution aerial photography and a digital photogrammetry system. Geomorphology 2009, 111, 48-60. [CrossRef]

56. James, A.; Watson, D.; Hansen, W. Using LiDAR data to map gullies and headwater streams under forest canopy: South Carolina, USA. Catena 2007, 71, 132-144. [CrossRef]

57. Vandekerckhove, L.; Poesen, J.; Oostwoud Wijdenes, D. Thresholds for gully initiation and sedi-mentation in Mediterranean Europe. Earth Surf. Processes Landf. 2000, 25, 1201-1220. [CrossRef]

58. Dormann, C.F.; Elith, J.; Bacher, S.; Buchmann, C.; Carl, G.; Carré, G.; Marquéz, J.R.G.; Gruber, B.; Lafourcade, B.; Leitão, P.J.; et al. Collinearity: A review of methods to deal with it and a simulation study evaluating their performance. Ecography 2013, 36, 27-46. [CrossRef]

59. Vanmaercke, M.; Chen, Y.; Haregeweyn, N.; De Geeter, S.; Campforts, B.; Heyndrickx, W.; Tsunekawa, A.; Poesen, J. Predicting gully densities at sub-continental scales: A case study for the Horn of Africa. Earth Surf. Processes Landf. 2020, 45, 3763-3779. [CrossRef]

60. Bennett, S.J.; Wells, R.R. Gully erosion processes, disciplinary fragmentation, and technological innovation. Earth Surf. Processes Landf. 2019, 44, 46-53. [CrossRef]

61. Shahabi, H.; Jarihani, B.; Tavakkoli Piralilou, S.; Chittleborough, D.; Avand, M.; Ghorbanzadeh, O. A Semi-Automated ObjectBased Gully Networks Detection Using Different Machine Learning Models: A Case Study of Bowen Catchment, Queensland, Australia. Sensors 2019, 19, 4893. [CrossRef] [PubMed]

62. Walker, S.J.; Wilkinson, S.N.; van Dijk, A.I.; Hairsine, P.B. A multi-resolution method to map and identify locations of future gully and channel incision. Geomorphology 2020, 358, 107115. [CrossRef]

63. Shruthi, R.B.V.; Kerle, N.; Jetten, V. Object-based gully feature extraction using high spatial resolution imagery. Geomorphology 2011, 134, 260-268. [CrossRef]

64. Martha, T.R.; Kerle, N.; Jetten, V.; van Westen, C.J.; Kumar, K.V. Characterising spectral, spatial and morphometric properties of landslides for semi-automatic detection using object-oriented methods. Geomorphology 2010, 116, 24-36. [CrossRef]

65. Remondino, F.; Barazzetti, L.; Nex, F. ISPRS-International Archives of the Photogrammetry. Remote Sens. Spat. Inf. Sci. 2011, XXXVIII-1/C22, 25-31. [CrossRef]

66. Nachtergaele, J.; Poesen, J.; Vandekerckhove, L.; Oostwoud Wijdenes, D.; Roxo, M. Testing the ephemeral gully erosion model (EGEM) for two Mediterraneanenvironments. Earth Surf. Processes Landf. 2001, 26, 17-30. [CrossRef]

67. Nachtergaele, J.; Poesen, J.; ASteegen, A.; Takken, I.; Beuselinck, L.; Vandekerckhove, L.; Govers, G. The value of a physically based model versus an empirical approach in the prediction of ephemeral gully erosion for loess-derived soils. Geomorphology 2001, 40, 237-252. [CrossRef]

68. K1lıç, O. Effects of land use and land cover changes on soil erosion in semi-arid regions of Turkey; a case study in Almus lake watershed. Carpathian J. Earth Environ. Sci. 2021, 16, 129-138. [CrossRef]

69. Fernandes, J.; Bateira, C.; Soares, L.; Faria, A.; Oliveira, A.; Hermenegildo, C.; Moura, R.; Gonçalves, J. SIMWE model application on susceptibility analysis to bank gully erosion in Alto Douro Wine Region agricultural terraces. Catena 2017, 153, 39-49. [CrossRef]

70. Olivares, B.; Verbist, K.; Silva, O.; Lobo, D.; Vargas, R. Evaluation of the USLE model to estimate water erosion in an Alfisol. Soil Sci. Plant Nutr. 2011, 11, 71-84. [CrossRef]

71. Beckedahl, H.R.; Bowyer-Bower, T.A.S.; Dardis, G.F.; Hanvey, P.M. Geomorphic Effects of Soil Erosion; Moon, B.P., Dardis, G.F., Eds.; The Geomorphology of Southern Africa, Southern Book Co.: Johannesburg, South Africa, 1988; pp. 249-276.

72. Kakembo, V.; Rowntree, K.M. The relationship between land use and soil erosion in the communal lands near Peddie Town, Eastern Cape, South Africa. Land Degrad. Dev. 2003, 14, 39-49. [CrossRef]

73. Elwell, H.; Stocking, M. Vegetal cover to estimate soil erosion hazard in Rhodesia. Geoderma 1976, 15, 61-70. [CrossRef]

74. De Ploey, J. Modelling the erosional susceptibility of catchments in terms of energy. Catena 1990, 17, 175-183. [CrossRef] 
75. Francis, C.F.; Thornes, J.B. Runoff Hydrographs from Three Mediterranean Vegetation Cover Types. In Vegetation and Erosion: Processes and Environments; Thornes, J.B., Ed.; Wiley: Chichester, UK, 1990; pp. 363-385.

76. Roxo, M.J. A Acção Antrópica no Processo de Degradação de Solos: A Serra de Serpa e Mértola. Ph.D. Thesis, Universidade Nova de Liboa, Lisboa, Portugal, 1994.

77. Bochet, E.; Rubio, J.L.; Poesen, J. Modified topsoil islands within patchy Mediterranean vegetation in SE Spain. Catena 1999, 38, 23-44. [CrossRef]

78. Zuazo, V.H.D.; Martínez, J.R.F.; Pleguezuelo, C.R.R.; Raya, A.M.; Rodríguez, B.C. Soil-erosion and runoff prevention by plant covers in a mountainous area (SE Spain): Implications for sustainable agriculture. Environmentalist 2006, 26, 309-319. [CrossRef]

79. Sonneveld, B.; Keyzer, M.A. Land under pressure: Soil conservation concerns and opportunities for Ethiopia. Land Degrad. Dev. 2003, 14, 5-23. [CrossRef]

80. Descroix, L.; Claude, J.-C. Spatial and temporal factors of erosion by water of black marl in the badlands of the French Southern Alps. Hydrol. Sci. J. 2002, 47, 227-242. [CrossRef]

81. Desmet, P.J.J.; Govers, G. A GIS procedure for automatically calculating the USLE LS factor on topographically complex landscape units. J. Soil Water Conserv. 1996, 51, 427-433.

82. Knapen, A.; Poesen, J. Soil erosion resistance effects on rill and gully initiation points and dimensions. Earth Surf. Processes Landf. 2009, 35, 217-228. [CrossRef]

83. Daggupati, P.; Yen, H.; White, M.J.; Srinivasan, R.; Arnold, J.G.; Keitzer, C.S.; Sowa, S.P. Impact of model development, calibration and validation decisions on hydrological simulations in West Lake Erie Basin. Hydrol. Process. 2015, 29, 5307-5320. [CrossRef]

84. Nearing, M.A.; Foster, G.R.; Lane, L.J.; Finkner, S.C. A Process-Based Soil Erosion Model for USDA-Water Erosion Prediction Project Technology. Trans. ASAE 1989, 32, 1587-1593. [CrossRef] 